Agric. Biol. Chem., 42 (11), 2045 2056, 1978

\title{
Purification and Characterization of Particulate Alcohol Dehydrogenase from Gluconobacter suboxydans ${ }^{\dagger}$
}

\author{
Osao Adachi, Kenji Tayama, Emiko Shinagawa, \\ Kazunobu Matsushita and Minoru AmEYama \\ Laboratory of Applied Microbiology, Department of Agricultural Chemistry, \\ Faculty of Agriculture, Yamaguchi University, Yamaguchi 753, Japan
}

Received May 29, 1978

\begin{abstract}
Particulate alcohol dehydrogenase of acetic acid bacteria that is mainly participated in vinegar fermentation was purified to homogeneous state from Gluconobacter suboxydans IFO 12528. Solubilization of enzyme from the bacterial membrane fraction by Triton X-100 and subsequent fractionation on DEAE-Sephadex A-50 and hydroxylapatite was successful in enzyme purification. A cytochrome c-like component was tightly bound to the dehydrogenase protein and existed as an enzyme-cytochrome complex. It was also confirmed that the alcohol dehydrogenase is not a cytochrome component itself. The molecular weight of the enzyme was determined to be 150,000 , and gel electrophoresis showed the presence of three subunits having a molecular weight of $85,000,49,000$ and 14,400. The smallest subunit was corresponded to the cytochrome $c$-like component. Ethanol was oxidized in the presence of dyes in vitro but NAD or NADP were not required as hydrogen acceptor. Unlike NADlinked alcohol dehydrogenase in yeast or liver and other primary alcohol dehydrogenases in methanol utilizing bacteria, the enzyme from the acetic acid bacteria showed its optimum $\mathrm{pH}$ at fairly acidic $\mathrm{pH}$.
\end{abstract}

The world of acetic acid bacteria has been classified into two genera, Acetobacter and Gluconobacter. ${ }^{1)}$ One of the aspects of this classification is based on their physiological characteristics in carbohydrate metabolism; for examples, production of acetic acid from ethanol is strong in Acetobacter, weak to negligible in Gluconobacter, production of gluconic acid from glucose is weak to negligible in Acetobacter, strong in Gluconobacter, and ketogenic activity is weak or none in Acetobacter, strong in Gluconobacter. Nonphosphorylative carbohydrate metabolism has been known as a predominant metabolic pathway in the acetic acid bacteria ${ }^{2)}$ as well as in other oxidative bacteria of such genera as Pseudomonas, ${ }^{3 \sim 5}$, Serratia $^{6}$ and Klebsiella. ${ }^{2)}$ Some of the important problems, however, still remain to be elucidated, such as, why and how the organisms accumulate acetic acid in high concentration so rapidly in Acetobacter, and gluconic acid

t A part of this work was presented at the Annual Meeting of the Agricultural Chemical Society of Japan, Nagoya, April 2, 1978, p. 119. and/or ketogluconic acids in Gluconobacter. Additionally, it has not been clarified why they are so strict aerobe and why they don't grow so fast and make a mass cell population even though a nutritionally rich medium is devised.

In the course of our investigation on the nonphosphorylative metabolic pathway of carbohydrates in acetic acid bacteria and other oxidative bacteria, many kinds of enzymes concerning ketogluconate metabolism have been prepared in pure form from these bacteria ${ }^{7 \sim^{16} \text { ) }}$ and studied in some details. ${ }^{17 \sim 22)}$ Our understandings have proceeded that the enzymes involved in the nonphosphorylative ketogluconate metabolism of the oxidative bacteria is divided into two groups. One is pyridine nucleotide dependent enzymes such as 2-ketogluconate reductase $\mathrm{e}^{7,9 \sim 11,15)}$ and 5-ketogluconate reductase ${ }^{8,21)}$ and the other is characterized as membrane bound particulate dehydrogenases. ${ }^{11 \sim 14,16)}$ The latter group involves glucose dehydrogenase, gluconate dehydrogenase, ketogluconate dehydrogenase, sorbitol dehydrogenase, alcohol dehydrogenase and so on. 
These particulate enzymes are independent on the pyridine nucleotide coenzymes in their enzyme activities and play an important role in the production of oxidative fermentation products such as gluconic acid, ketogluconic acids, sorbose, dihydroxyacetone, acetic acid and others.

A sole report concerning alcohol oxidation by acetic acid bacteria has been made by Sekuzu et al. $^{23)}$ and Nakayama ${ }^{24}$ that a highly purified cytochrome c component prepared from $A$. peroxydans is accompanied with alcohol dehydrogenase activity. In the course of our studies on ketogluconate metabolism of acetic acid bacteria, a series of particulate enzymes of glucose dehydrogenase, gluconate dehydrogenase, ketogluconate dehydrogenase, sorbitol dehydrogenase and alcohol dehydrogenase have been shown to be cytochrome-linked enzyme. ${ }^{11 \sim 14,16,21,22)}$ In this paper, we wish to describe the purification and characterization of particulate alcohol dehydrogenase from G. suboxydans. An evidence will be presented that a protein dehydrogenating alcohol is not a cytochrome c component itself, but exists as an enzyme-cytochrome complex.

\section{METHODS AND MATERIALS}

Chemicals. All chemicals used in this study were commercial preducts. Yeast extract and NAD(P) and its reduced forms were generously supplied from the Oriental Yeast Ind. Co., Ltd. Sodium gluconate and glucose for culture medium were kind gift from the Fujisawa Pharmaceutical Ind. Co., Ltd. Hydroxylapatite was prepared according to Tiselius et al. ${ }^{253}$ Potato extract was prepared as mentioned by Ameyama and Kondo. ${ }^{26)}$

Microorganisms. Bacterial strains of genus Gluconobacter, listed in Table I, were generous donation from the Institute for Fermentation, Osaka (IFO). As reported by Asai, ${ }^{2)}$ gluconobacters grow on glucose or gluconate and produce a marked amount of 5-ketogluconate as well as 2-ketogluconate. G. suboxydans IFO 12528 was selected for further extensive study of the particulate alcohol dehydrogenase and in other experiments on 5-ketogluconate reductase and 5-ketogluconate producing gluconate dehydrogenase. ${ }^{27}$ ) The growing cells and resting cells of gluconobacters utilized ethanol but the accumulation of acetic acid was not so high as acetobacters in cell level experiments. ${ }^{29}$ ?
Medium and cultivation. The culture medium of gluconobacter was consisted of $20 \mathrm{~g}$ of sodium gluco. nate, $5 \mathrm{~g}$ of glucose, $3 \mathrm{~g}$ of glycerol, $3 \mathrm{~g}$ of yeast extract, $2 \mathrm{~g}$ of polypeptone and $200 \mathrm{ml}$ of potato extract in 1 liter of tap water. The $\mathrm{pH}$ of the medium was spontaneously settled on 6.5 when all these ingredients were mixed. Gluconobacters were transferred from the potato extract-agar slant to $100 \mathrm{ml}$ of the medium in $500 \mathrm{ml}$ shaking flask and the cultivation was carried out at $30^{\circ} \mathrm{C}$ for $24 \mathrm{hr}$ with reciprocal shaking. In case of large scale culture, 1.5 liters of inoculum (15 shaking flasks) were transferred into 30 liters of the medium in 50-liter jar fermentor. In this case, the potato extract was usually omitted from the medium and cultivation was performed at $30^{\circ} \mathrm{C}$ for $24 \mathrm{hr}$ under vigorous aeration at 30 liters per min with $500 \mathrm{rpm}$ agitation.

Enzyme assay. Following assay systems were available: ethanol was oxidized by particulate alcohol dehydrogenase (1) by spectrometry in the presence of 2,6-dichlorophenolindophenol and phenazine methosulfate, (2) by colorimetry in the presence of ferricyanide and (3) by polarometry with oxygen electrode or (4) by manometry in a conventional Warburg apparatus. In this study, assay method with ferricyanide was mainly employed in its simplicity for routine assay. This method was employed by Wood et al. ${ }^{20)}$ in the assay of gluconate dehydrogenase of Pseudomonas fuorescens using ferricyanide as an electron carrier. Some modifcations are made as also reported elsewhere. ${ }^{z 0}$ ) The rate of reduction of ferricyanide to ferrocyanide gives a quantitative amount of ethanol oxidized. The reaction mixture contained $10 \mu$ moles of potassium ferricyanide, $0.5 \mathrm{ml}$ of Mcllvaine buffer, pH 5.5, enzyme solution and $100 \mu$ moles of ethanol in a total volume of $1.0 \mathrm{ml}$. The reaction was carried out at $37^{\circ} \mathrm{C}$ by the addition of ethanol solution, and stopped by adding $0.5 \mathrm{ml}$ of the ferric-Dupanol reagent. ${ }^{29}$ ) Then, $3.5 \mathrm{ml}$ of water was further added to the reaction mixture and well mixed. The resulting stabilized Prussian blue color formed was measured spectrophotometrically at $660 \mathrm{~nm}$ after standing for $20 \mathrm{~min}$ at $37^{\circ} \mathrm{C}$. One unit of enzyme activity was defined as the amount of enzyme catalyzing the oxidation of $1 \mu$ mole of ethanol per min under these assay conditions and 4.0 absorbance unit equaled to $1 \mu$ mole of ethanol oxidized.

Protein determination. Protein content was determined according to the method by Lowry et al., ${ }^{\text {st) }}$ using a bovine serum albumin as the standard. A modified method described by Dulley and Grieve ${ }^{32)}$ was employed instead for the samples which contained Triton X-100.

Electrophoresis. For estimation of purity of the enzyme preparations, disc gel electrophoresis was performed under essentially the same conditions as de- 
scribed by Davis ${ }^{38}$ using $7.5 \%$ of polyacrylamide gel and Tris-glycine buffer, pH 8.3. Sodium dodecyl sulfate (SDS)-acrylamide gel electrophoresis was performed to determine molecular weight of the purified enzyme under essentially the same conditions of Weber and Osborn. ${ }^{\text {s4) }}$ Free boundary electrophoresis of the purified enzyme was performed to estimate the occurrence of dissociation of enzyme at $\mathrm{pH} 6.0$ of phosphate buffer of 0.1 ionic strength. After passage of $10.0 \mathrm{~mA}$ current for $180 \mathrm{~min}$, each 25 drops were collected and subjected to further analyses.

Analytical ultracentrifugation. Estimation of sedimentation velocity and examination of purity of the purified enzyme was carried out with a Hitachi model UCA-1A analytical ultracentrifuge at $59,780 \mathrm{rpm}$ using a schlieren optics. ${ }^{85)}$ Temperature was maintained at $20^{\circ} \mathrm{C}$ throughout the measurement.

\section{RESULTS AND DISCUSSION}

Distribution of particulate alcohol dehydrogenase in gluconobacters

Distribution of particulate alcohol dehydro- genase was surveyed with cell homogenate of the genus Gluconobacter as shown in Table I. High enzyme activity was found in cell homogenate from three strains of $G$. dioxyacetonicus, both strains of $G$. nonoxygluconicus, two strains of $G$. cerinus IFO 3267 and IFO 3269 and $G$. suboxydans IFO 12528 showed the highest enzyme activity under these experimental conditions. It was also interesting that, despite of fairly well growth on the medium, a poor enzyme activity was observed with all strains of $G$. suboxydans var. $\alpha$. As expected, all enzyme activity occurred in the particulate membrane fraction when the cell homogenate of several gluconobacters was centrifuged at $100,000 \times g$ for $60 \mathrm{~min}$. These results also suggested the possibility to solubilize the enzyme by a surface active agent, and the solubilization could actually performed by Triton X-100. Extraction of the enzyme was also done with acetone dried cell as mentioned by Naka-

Table I. Distribution of Particulate Alcohol Dehydrogenase in Gluconobacters

Each strain of gluconobacters was inoculated on three shaking flasks ( $300 \mathrm{ml}$ of the medium) and incubated at $30^{\circ} \mathrm{C}$ for $24 \mathrm{hr}$ under reciprocal shaking. Enzyme activity was assayed with cell homogenate under the standard assay conditions. Results are expressed by total enzyme activity and the parenthesis means specific activity (units/mg protein).

\begin{tabular}{|c|c|c|c|c|c|}
\hline Strain & A & $\mathrm{D} \mathrm{H}^{a}$ & Strain & $\mathrm{A}$ & $\mathrm{H}^{a}$ \\
\hline G. liquefaciens IFO 12388 & 4 & $(0.1)$ & G. gluconicus IFO 3286 & 37 & $(0.2)$ \\
\hline G. melanogenus IFO 12257 & 75 & $(0.6)$ & G. roseus IFO 3990 & 59 & $(0.8)$ \\
\hline G. melanogenus IFO 12258 & 13 & $(0.1)$ & G. albidus IFO 3250 & $\operatorname{tr}$ & \\
\hline G. melanogenus IFO 3293 & 143 & $(0.6)$ & G. albidus IFO 3251 & 133 & $(0.6)$ \\
\hline G. melanogenus IFO 3294 & 218 & $(1.3)$ & G. albidus IFO 3253 & 174 & $(1.2)$ \\
\hline G. sphaericus IFO 12467 & $\operatorname{tr}$ & & G. suboxydans IFO 3130 & 24 & $(0.2)$ \\
\hline G. oxydans IFO 3189 & 13 & $(0.1)$ & G. suboxydans IFO 3172 & 51 & $(0.3)$ \\
\hline G. oxydans IFO 3287 & 261 & $(1.7)$ & G. suboxydans IFO 3289 & 120 & $(0.6)$ \\
\hline G. dioxyacetonicus IFO 3271 & 267 & $(1.5)$ & G. suboxydans IFO 3290 & 53 & $(0.3)$ \\
\hline G. dioxyacetonicus IFO 3272 & 428 & (2.2) & G. suboxydans IFO 3291 & 118 & $(0.7)$ \\
\hline G. dioxyacetonicus IFO 3274 & 462 & $(2.0)$ & G. suboxydans IFO 12528 & 635 & $(4.2)$ \\
\hline G. cerinus IFO 3262 & 64 & $(0.4)$ & G. suboxydans var. $\alpha$ IFO 3254 & $\operatorname{tr}$ & \\
\hline G. cerinus IFO 3263 & 4 & $(0.1)$ & G. suboxydans var. a IFO 3255 & $\operatorname{tr}$ & \\
\hline G. cerinus IFO 3264 & 57 & $(0.4)$ & G. suboxydans var. $\alpha$ IFO 3256 & $\operatorname{tr}$ & \\
\hline G. cerinus IFO 3265 & 16 & $(0.1)$ & G. suboxydans var. $\alpha$ IFO 3257 & $\operatorname{tr}$ & \\
\hline G. cerinus IFO 3266 & $\operatorname{tr}$ & & G. suboxydans var. $\alpha$ IFO 3258 & $\operatorname{tr}$ & \\
\hline G. cerinus IFO 3267 & 361 & $(2.2)$ & G. capsulatus IFO 3462 & 108 & $(1.0)$ \\
\hline G. cerinus IFO 3268 & 71 & $(0.5)$ & G. industrius IFO 3260 & $\operatorname{tr}$ & \\
\hline G. cerinus IFO 3269 & 431 & $(2.3)$ & G. nonoxygluconicus IFO 3275 & 495 & $(2.6)$ \\
\hline G. cerinus IFO 3270 & 129 & $(0.9)$ & G. nonoxygluconicus IFO 3276 & 450 & $(1.9)$ \\
\hline G. gluconicus IFO 3171 & $\operatorname{tr}$ & & G. rubiginosus IFO 3244 & 432 & $(2.1)$ \\
\hline G. gluconicus IFO 3285 & 57 & $(0.4)$ & & & \\
\hline
\end{tabular}

a Particulate alcohol dehydrogenase activity is abbreviated as A D H. 
yama. ${ }^{24}$ It was found that extraction and solubilization of the enzyme without the aid of detergent caused polymerization, most of which was dimer, and made the enzyme less stable as briefly mentioned later.

\section{Enzyme formation during the cultivation}

Time course of enzyme formation in cell of G. suboxydans IFO 12528 during the growth was estimated. As shown in Fig. 1, a maximal formation of the total enzyme activity of particulate alcohol dehydrogenase was observed at the end of exponential phase of bacterial growth. Similar results were obtained with other enzyme species of acetic acid bacteria such as $G$. liquefaciens, ${ }^{7,8} G$. suboxydans var. $\alpha{ }^{28)}$ A. rancens, ${ }^{10)}$ A ascendens ${ }^{15}$ and other oxidative bacteria of $P$. aeruginosa, $K$. aerogenes and $S$. marcescens. ${ }^{36)}$ A typical sequential enzyme formation was also recorded in fermentation engineering experiments with $G$. suboxydans var. a performed in a well controlled jar fermentor. ${ }^{28}$ When glucose was added as the carbon source, of the particulate dehydrogenases, the first enzyme appeared was glucose dehydrogenase and a comparable amount of gluconate was accumulated in the

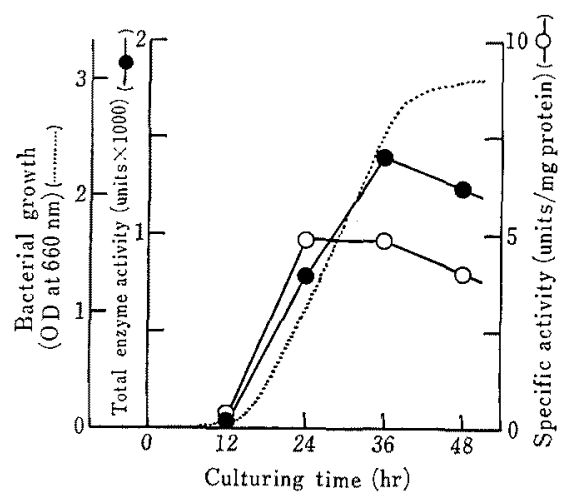

Fig. 1. Time Course of Particulate Alcohol Dehydrogenase Formation.

Three shaking cultured flasks ( $300 \mathrm{ml}$ of the medium) were harvested after $12 \mathrm{hr}$ interval. Bacterial growth was measured from the turbidity of culture broth at $660 \mathrm{~nm}$ and expressed by dotted line. Enzyme activity, (๑), and protein content were measured with cell homogenate. Specific activity, $(0)$, was expressed as units per mg protein. culture broth at the middle exponential phase. Gluconate in the culture broth spontaneously facilitated the formation of gluconate dehydro. genase, ketogluconate dehydrogenase and alcohol dehydrogenase. The $\mathrm{pH}$ of the medium was rapidly lowered to 4.3 within $24 \mathrm{hr}$ and maintained at a constant level throughout the culture for about $120 \mathrm{hr}$ so far tested. As mentioned briefly in the METHODS AND MATERIALS, the growing cells or resting cells of gluconobacters rapidly oxidize glucose, gluconate and other substrates including ethanol. There was a marked difference between gluconobacters and other oxidative bacteria that an appreciable oxidation of ethanol was seen in gluconobacters but not in other oxidative bacteria. ${ }^{22)}$ The broken cell of gluconobacters (cell homogenate) revealed a marked activity of ethanol oxidation much more than intact cells. Two times or more enzyme activity of glucose oxidation or gluconate oxidation was also usually present in the cell homogenate comparing with intact cells.

\section{Purification of particulate alcohol dehydrogenase}

All operations were carried out at $0 \sim 5^{\circ} \mathrm{C}$, unless otherwise stated. In the followings, centrifugation means a conventional run carried out at $12,000 \times g$ for $20 \mathrm{~min}$. Potassium phosphate buffer, $\mathrm{pH} 6.0$, containing $1 \mathrm{~mm} 2$ mercaptoethanol was basically used in this work.

\section{Preparation of particulate fraction}

Cell paste of $G$. suboxydans IFO 12528 ( $350 \mathrm{~g}$, wet wt.) which was harvested by continuous flow centrifugation from 90 liters of $24 \mathrm{hr}$ culture was washed twice with cold distilled water and then suspended in $0.01 \mathrm{M}$ buffer. The cell suspension was passed through a French pressure cell press at 20,000 psi. Cell debris was removed by centrifugation at $5000 \times g$ for $10 \mathrm{~min}$. To the cell homogenate, ammonium sulfate was added to 0.75 saturation and $\mathrm{pH}$ was adjusted to 6.0. After standing for $30 \mathrm{~min}$ in an ice bath, the resulting precipitate was collected and stored in a deep freezer at $-20^{\circ} \mathrm{C}$. The precipitate could be 
stored without any loss of enzyme activity for at least 6 months so far examined. The precipitate was dissolved in a small volume of $0.01 \mathrm{M}$ buffer and dialyzed against the same buffer to remove ammonium sulfate thoroughly. Almost of enzyme activity was recovered in this dialyzed solution.

\section{Solubilization of enzyme from the particulate fraction}

Solubilization of the enzyme was performed as essentially the same as mentioned before. ${ }^{11}$ The protein concentration of the dialyzed enzyme solution was adjusted to $30 \mathrm{mg}$ per $\mathrm{ml}$ with the dialyzing buffer and the enzyme solution was incubated for $3 \mathrm{hr}$ at $0^{\circ} \mathrm{C}$ with gentle stirring in the presence of $1 \%$ Triton $\mathrm{X}-100$. The enzyme solution was then spun down to remove insoluble materials and a reddish supernatant was obtained as the solubilized enzyme.

\section{DEAE-Sephadex column chromatography}

The solubilized enzyme was dialyzed against $0.002 \mathrm{M}$ buffer containing $0.1 \%$ Triton $\mathrm{X}-100$ overnight. Dialyzed enzyme solution was applied on a column of DEAE-Sephadex A-50 $(5 \times 30 \mathrm{~cm})$, which had been equilibrated with the same buffer and washed with additional $500 \mathrm{ml}$ of the buffer. Enzyme activity was eluted from the column with a linear gradient of phosphate up to $0.1 \mathrm{M}$, and the enzyme activity was eluted at around $0.05 \mathrm{M}$ of phosphate concentration. Pooled enzyme fraction was then dialyzed against $0.002 \mathrm{M}$ buffer containing $0.05 \%$ Triton X-100 overnight. Chromatography on DEAE-Sephadex A-50 was repeated. After adsorption of the enzyme into a column of DEAE-Sephadex A-50 (1.5 $\times$ $20 \mathrm{~cm}$ ), the column was first treated with $0.015 \mathrm{M}$ buffer containing $0.05 \%$ Triton $\mathrm{X}-100$ and elution of the enzyme was performed by a linear gradient elution made between $0.015 \mathrm{M}$ and $0.1 \mathrm{M}$ of phosphate buffer. Each buffer reservior contained $500 \mathrm{ml}$ and $0.05 \%$ Triton $X-100$ was present throughout this step. This second step of DEAE-Sephadex A-50 chromatography was found convenient to bring about in removing an impurity which was co- chromatographed in the next step. Pooled enzyme fraction was dialyzed against $0.01 \mathrm{M}$ buffer containing $0.05 \%$ Triton $\mathrm{X}-100$ overnight.

\section{Hydroxylapatite column chromatography}

The dialyzed enzyme solution was divided into three portions and each portion was adsorbed separately into a hydroxylapatite column $(1.5 \times 5 \mathrm{~cm})$, which had been equilibrated with the same buffer and the column was washed with $150 \mathrm{ml}$ of the buffer. The column was then treated stepwise with $0.02 \mathrm{M}$, $0.05 \mathrm{M}$ and $0.1 \mathrm{M}$ buffer containing $0.1 \%$ Triton X-100. Almost of enzyme activity was eluted at $0.1 \mathrm{M}$ concentration of phosphate. As can be seen in Fig. 2, elution pattern of this column chromatography gave a symmetric protein peak with accompanying corresponding enzyme activity and rose-red color intensity. Specific activity around the peak fractions showed a constant level and fractions of which specific activity over 175 were collected. Pooled enzyme solution was concentrated by a Toyo ultra filter UP-20. Summary of a typical purification of the enzyme is shown in Table II, and the enzyme was purified about

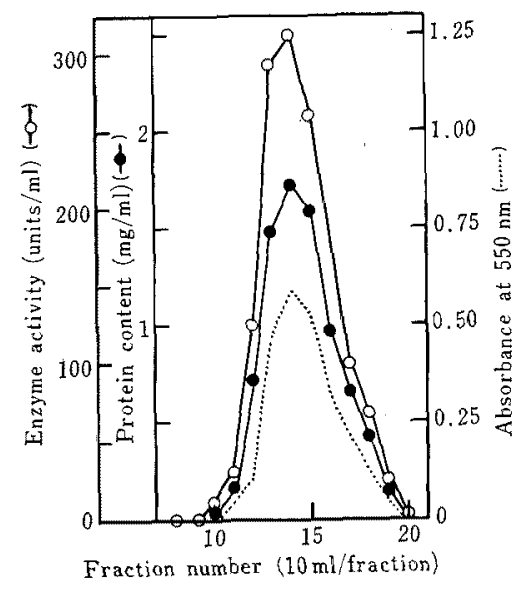

FIG. 2. Chromatography on Hydroxylapatite Column.

Protein, $180 \mathrm{mg}$, containing 23,600 units of enzyme activity was applied to a column $(1.5 \times 5 \mathrm{~cm})$, which had been equilibrated with $0.01 \mathrm{M}$ buffer containing $0.1 \%$ Triton X-100. Enzyme activity was eluted with $0.1 \mathrm{~m}$ buffer containing $0.1 \%$ Triton $\mathrm{X}-100$. Fractions of $10 \mathrm{ml}$ were collected at a flow rate of $3 \mathrm{ml}$ per hr. 
Table II. Summary of Purification of Particulate Alcohol Dehydrogenase' FROM Gluconobacter suboxydans

\begin{tabular}{|c|c|c|c|c|}
\hline $\begin{array}{l}\text { Purification } \\
\text { step }\end{array}$ & $\begin{array}{l}\text { Total } \\
\text { protein } \\
(\mathrm{mg})\end{array}$ & $\begin{array}{c}\text { Total } \\
\text { activity } \\
\text { (units) }\end{array}$ & $\begin{array}{c}\text { Specific } \\
\text { activity } \\
\text { (units } / \mathrm{mg} \text { ) }\end{array}$ & $\begin{array}{l}\text { Yield } \\
(\%)\end{array}$ \\
\hline Homogenate & 32,920 & 131,700 & 4 & $(100)$ \\
\hline \multicolumn{5}{|l|}{ Solubilized } \\
\hline fraction & 5,665 & 108,200 & 19 & 82 \\
\hline \multicolumn{5}{|l|}{ DEAE-Sephadex } \\
\hline$A-50(I)$ & 2,080 & 104,000 & 50 & 79 \\
\hline \multicolumn{5}{|l|}{ DEAE-Sephadex } \\
\hline A-50(II) & 550 & 71,400 & 130 & 54 \\
\hline Hydroxylapatite & 290 & 56,550 & 195 & 43 \\
\hline
\end{tabular}

50 -fold with an yield of 43 per cent.

Properties of purified particulate alcohol dehydrogenase

Absorption spectra. Purified particulate alcohol dehydrogenase of $G$. suboxydans showed a cytochrome c-like absorption spectra (Fig. 3). A hemeprotein was present as almost reduced form at the final enzyme preparation, suggesting that the hemeprotein was quite stable and less autooxidizable. Absorption maxima at the wavelength of $553 \mathrm{~nm}$, $522 \mathrm{~nm}$ and $417 \mathrm{~nm}$ were observed with the

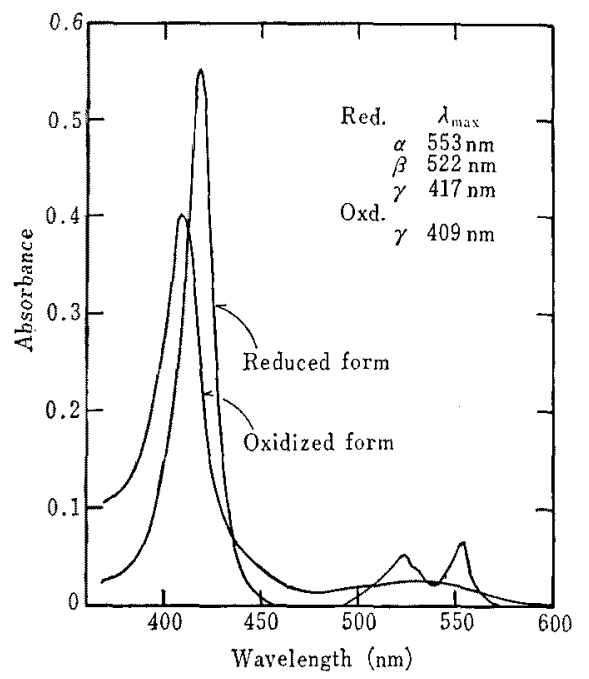

FIG. 3. Absorption Spectra of Particulate Alcohol Dehydrogenase from $G$. suboxydans.

Finally purified enzyme with a specific activity of 195 was used at concentrations of $0.1 \mathrm{mg}$ per $\mathrm{ml}$ for reduced form and $0.1 \mathrm{mg}$ per $\mathrm{ml}$ for oxidized form, in $0.01 \mathrm{~m}$ buffer containing $0.1 \%$ Triton X-100. reduced enzyme and a sole peak at $409 \mathrm{~nm}$ was observed with the oxidized enzyme. In the ultraviolet region, absorption spectra could not examine successfully due to the presence of an excess amount of Triton X-100 in the enzyme solution. These absorption spectra were fairly similar to those of cytochrome $\mathrm{c}$ judging from the literatures by Okunuki and his coworkers. $^{37 \sim 39)}$ The absorption spectra were also quite similar to those from $A$. peroxydans, ${ }^{24)}$ but an apparent molecular size of the enzyme was somewhat different as mentioned below. Difference spectrum was also taken with reduced form versus oxidized form as shown in Fig. 4. A marked reduction of absorption around $450 \sim 460 \mathrm{~nm}$ suggested the presence of flavocomponent in the purified enzyme. These results from spectral study indicate that the alcohol dehydrogenase is consisted of heterogeneous components of hemeprotein, flavoprotein and others, and has a function as an enzyme complex.

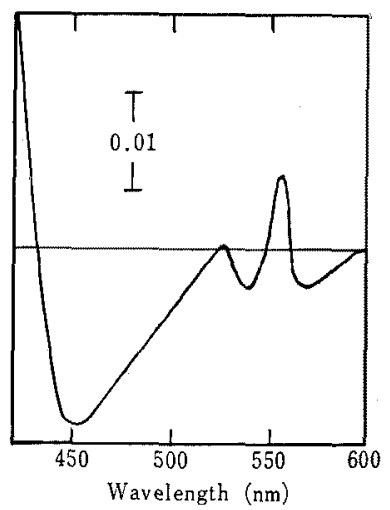

FIG. 4. Difference Spectrum of Particulate Alcohol Dehydrogenase from $G$, suboxydans.

Spectrum was taken at the enzyme concentration of $0.018 \mathrm{mg}$ per $\mathrm{ml}$ of which specific activity was 195 . Sodium dithionite-reduced enzyme was set at sample cuvette and oxidized enzyme at $\mathrm{pH} 9$ was placed in the reference hole of a Hitachi recording spectrophotometer model 124.

Homogeneity. Homogeneity of the purified enzyme was estimated by an analytical ultracentrifuge and the sedimentation pattern of the enzyme showed a single symmetrical peak (Fig. 5). The faster moving peak which 


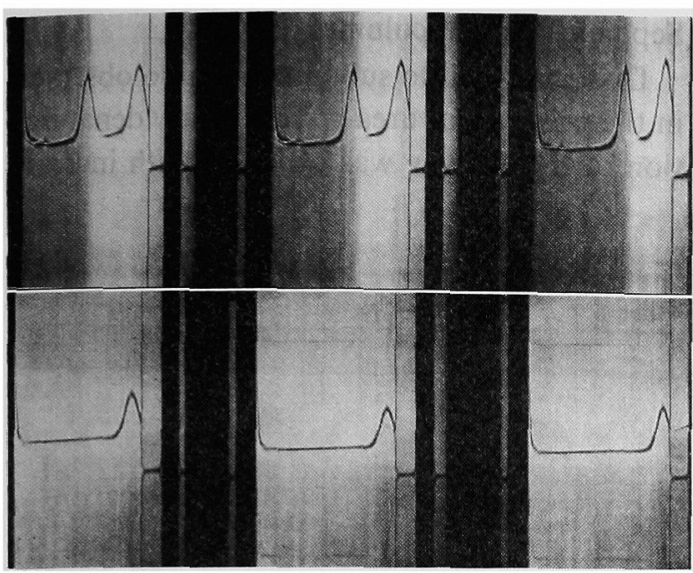

FIG. 5. Sedimentation Pattern of Particulate Alcohol Dehydrogenase from $G$. suboxydans.

Finally purified enzyme with a specific activity of 195 was used at the enzyme concentration of $11.1 \mathrm{mg}$ per $\mathrm{ml}$ in $0.01 \mathrm{M}$ buffer containing about $0.1 \%$ Triton $\mathrm{X}-100$. Photographs were taken at $44 \mathrm{~min}, 52 \mathrm{~min}$ and $60 \mathrm{~min}$ after reaching at $59,780 \mathrm{rpm}$. Upper frame, particulate alcohol dehydrogenase; lower frame, Triton X-100 at $5 \mathrm{mg}$ per $\mathrm{ml}$ in $0.01 \mathrm{M}$ buffer. Direction of sedimentation was right to left.

had a rose-red colored was corresponded to the particulate alcohol dehydrogenase, and the slower sedimenting component was confirmed to be Triton $\mathrm{X}-100$ which was present in excess in the enzyme solution. As a reference, $5 \mathrm{mg}$ per $\mathrm{ml}$ of Triton $\mathrm{X}-100$ was separately run under the same analytical conditions as also shown in Fig. 5. An apparent sedimentation constant of the enzyme was calculated to be $5.9 S$ and that of Triton $\mathrm{X}-100$ was found to be $1.9 \mathrm{~S}$. Cytochrome $\mathrm{c}$ having an alcohol dehydrogenase activity from $A$. peroxydans showed $10.3 S$ of sedimentation constant ${ }^{24)}$ and the value was almost twice as much as our preparation. Gel filtration of the enzyme on a Sephadex G-200 column was also done to estimate whether any impurity was present and to determine an apparent molecular weight. No appreciable minor component was detected from the gel filtration chromatogram and an apparent molecular weight was obtained to be approximately 150,000 . Thus the purified particulate alcohol dehydrogenase was shown to be homogeneous and a cytochrome component was tightly bound to form an enzyme- cytochrome complex.

Electrophoretic analyses. When the purified enzyme was subjected to a conventional polyacrylamide gel electrophoresis prepared at $\mathrm{pH} 8.3$ and run at $\mathrm{pH} 9.5$, three protein bands were stained as shown in Fig. 6, trace-1. Enzyme activity was detected on the slowest moving protein band when the gel was incubated in the presence of phenazine methosulfate, nitroblue tetrazolium and ethanol at $\mathrm{pH} 5.5,{ }^{40)}$ as shown in Fig. 5, trace-2. When an unstained gel was irradiated by a fluorescent

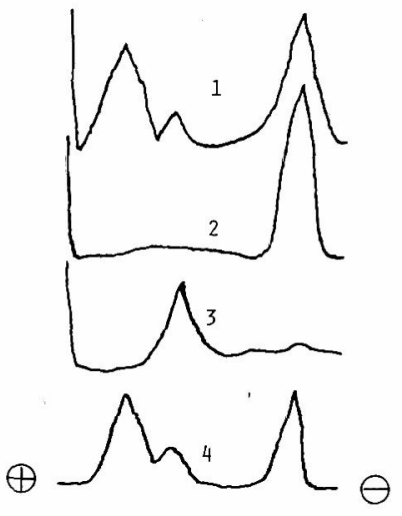

FIG. 6. Densitometric Traces of Polyacrylamide Gel Electrophoresis of Particulate Alcohol Dehydrogenase. Finally purified enzyme with a specific activity of 195 was used and applied to a gel column $(7.5 \%$ polyacrylamide) and run at $\mathrm{pH} 9.5$ for $2 \mathrm{hr}$ at $2 \mathrm{~mA}$. Trace-1, protein staining. Enzyme protein $(50 \mu \mathrm{g})$ was applied and stained by coomassie brilliant blue. Trace-2, enzyme activity staining. Enzyme activity was detected by staining the gel in a medium containing $100 \mathrm{~mm}$ ethanol, $0.4 \mathrm{mg}$ per $\mathrm{ml}$ of nitroblue tetrazolium, $0.14 \mathrm{mg}$ per $\mathrm{ml}$ of phenazine methosulfate and $0.1 \mathrm{M}$ buffer, pH 6.0. After the incubation for 5 to $10 \mathrm{~min}$ at $25^{\circ} \mathrm{C}$ in a dark, the reaction was stopped by dipping the gel into $7 \%$ acetic acid solution. Enzyme protein $(50 \mu \mathrm{g})$ was used and the unstained gel was bufferized at pH 6 before enzyme activity staining. Trace-3, localization of cytochrome component. Enzyme protein $(1 \mathrm{mg}$ ) was applied and unstained gel was immediately traced with a filter of $550 \mathrm{~nm}$. Trace-4, iron staining. Enzyme protein $(50 \mu \mathrm{g})$ was used and gel was stained by benzidine in a dark. After development of blue color, the gel was traced with a filter of $440 \mathrm{~nm}$. A Toyo Densitorol DMU-33C was used in this densitometric scanning. Direction of electrophoresis was right of left. 
light, strong intensity of fluorescens was observed only with the slowest moving protein band. This also indicated the presence of flavoprotein in the particulate alcohol dehydrogenase complex. When the unstained gel was traced with a filter of $550 \mathrm{~nm}$, a middle protein band with the least stained by coomassie brilliant blue was found to be the cytochrome c-like component (Fig. 6, trace-3). This band was usually visible when a lot of protein was treated by gel electrophoresis. These results confirmed that the alcohol dehydrogenase is not a cytochrome component itself and the cytochrome component, however, has a function as an electron acceptor in vivo, since the cytochrome component of the enzyme was readily reduced by the addition of ethanol to the enzyme solution. When the gel column was stained with benzidine to detect iron by nonspecific chelation, ${ }^{41)}$ and followed by densitometry at $440 \mathrm{~nm}$ (Fig. 6, trace-4), all three protein bands contained an appreciable amount of iron. The results obtained here indicate that electrophoresis at alkaline $\mathrm{pH}$ makes dissociation of the enzyme complex into subunits. Similar observations were reported with a purified particulate gluconate dehydrogenase from $K$. aerogenes ${ }^{13)}$ and $P$. aeruginosa, ${ }^{14)}$ which contained tightly bound cytochrome component, when the enzymes were treated at alkaline $\mathrm{pH}$. It was also supported from the fact that, when the particulate alcohol dehydrogenase was trated at $\mathrm{pH} 6.0$ in a conventional apparatus of free boundary electrophoresis for $180 \mathrm{~min}$ at 0.1 ionic strength, no dissociation occurred and retained its catalytic and physicochemical properties identical with native enzyme.

Dissociation into subunits was also observed by SDS-gel electrophoresis in the determination of molecular weight of the enzyme. In the presence of SDS, the enzyme was dissociated into three subunits with a molecular weight of $85,000,49,000$ and 14,400 from the top to bottom of the gel column as shown in Fig. 7. The sum of molecular weight of each band gave 150,000 of total molecular weight, which was in good agreement with the result of molecular weight determination by gel filtration by

\section{Sephadex G-200 column.}

Dissociation into subunits was also observed in the presence of urea. Temporary denaturation of the enzyme was observed with increas-

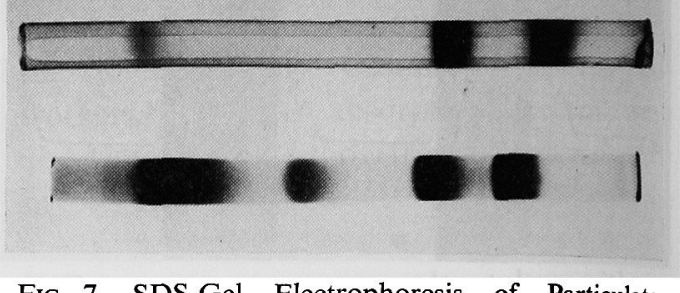

FIG. 7. SDS-Gel Electrophoresis of Particulate Alcohol Dehydrogenase.

Finally purified enzyme with a specific activity of 195 was used and $10 \mu$ of enzyme protein was applied (Upper column). Lower column, standard marker proteins. Standard marker proteins used were from right to left of the lower column were: bovine serum albumin, mol. wt. 68,000; ovalbumin, mol. wt. 43,000; trypsin, mol. wt. 23,300 and lysozyme, mol. wt. 14,300. Both columns were stained by coomassie brilliant blue. Direction of electrophoresis was right to left.

ing concentration of urea in the presence of $0.1 \mathrm{M}$ 2-mercaptoethanol at $\mathrm{pH} 6.0$, and immediate dilution gave a complete renaturation when traced by disappearance and reappearance of enzyme activity. Irreversible denaturation was observed by prolonged incubation of the enzyme with urea at $3 \mathrm{M}$ for over $60 \mathrm{hr}$ in the presence of $0.1 \mathrm{M} \mathrm{2-mercapto-}$ ethanol at $\mathrm{pH}$ 6.0. The urea-denatured enzyme solution was applied to a Sephadex G-150 column $(1.5 \times 30 \mathrm{~cm})$, which had been equilibrated with $0.01 \mathrm{M}$ buffer containing $3 \mathrm{M}$ urea and $0.1 \mathrm{M} 2$-mercaptoethanol. Elution pattern of the urea-denatured enzyme was shown in Fig. 8-A. It was obvious that the enzyme was dissociated into three subunits as similarly observed by SDS-gel electrophoresis. Each three peaks and original denatured enzyme solution were run on an SDS-gel column separately as also shown in Fig. 8-B.

No attempt has been made to reconstitute the alcohol dehydrogenase complex from the dissociated and separately purified subunit. Two of three subunits of the enzyme has been 

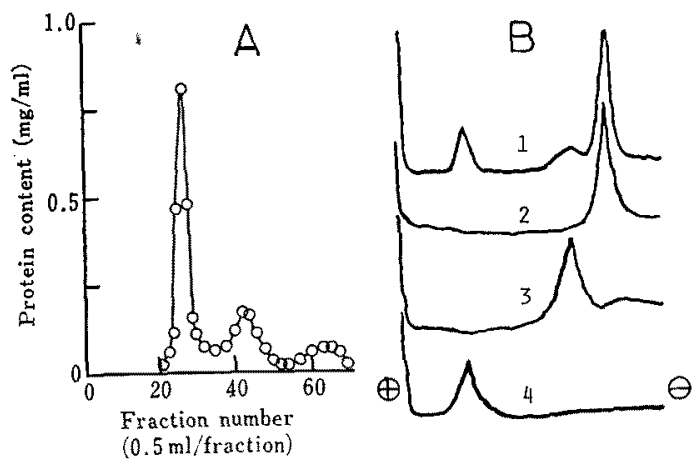

Fig. 8. Gel Filtration of Urea-denatured Enzyme on Sephadex G-150 Column (A) and SDS-Gel Electrophoresis of Denatured Components after Gel Filtration (B).

Finally purified enzyme with a specific activity of 195 $(10 \mathrm{mg}$ ) was dialyzed for 4 days against $3 \mathrm{M}$ urea in $0.01 \mathrm{M}$ buffer containing $0.1 \mathrm{M} 2$-mercaptoethanol and $0.1 \%$ Triton $\mathrm{X}-100$. The dialyzed solution was applied to a column of Sephadex $\mathrm{G}-150(1.5 \times 30 \mathrm{~cm})$, which had been equilibrated with the dialyzing buffer. Fractions of each $0.5 \mathrm{ml}$ were collected. SDS-Gel electrophoresis was performed after gel filtration and densitometric traces were shown with peak fractions and the original denatured enzyme solution. Trace-1, original denatured enzyme solution; Trace-2, fraction No. 27; Trace-3, fraction No. 42 and Trace-4, fraction No. 63. Direction of gel electrophoresis was right to left.

partially characterized, one is cytochrome clike hemeprotein and the other is flavoprotein to which substrate, ethanol, first binds. The third subunit with the fastest mobility in polyacrylamide gel at $\mathrm{pH} 9.5$ has not been characterized.

These results suggest that the purified enzyme preparation of the particulate alcohol dehydrogenase from $G$. suboxydans is composed of three different subunits and made up an enzyme complex of dehydrogenase and hemeprotein. It might be quite possible that the cytochrome $\mathrm{c}$ having alcohol dehydrogenase activity from A. peroxydans, of which molecular weight of $250,000,{ }^{24}$ is composed of heterogeneous subunits and the alcohol dehydrogenase activity is not due to cytochrome $\mathrm{c}$ component itself. It could be expected that if such enzyme is treated at alkaline $\mathrm{pH}, \mathrm{SDS}$, urea or other denaturants, dissociation into subcomponents probably occur, and it will be clarified that a protein component free from cytochrome $\mathrm{c}$ has an enzyme activity as mentioned above. Indeed, similar results have been obtained with particulate alcohol dehydrogenase from other species of acetic acid bacteria such as $G$. liquefaciens, A. aceti and Acetobacter sp. in our laboratory as reported elsewhere. ${ }^{16}$,

\section{Properties of catalytic activity}

The particulate alcohol dehydrogenase could be assayed in vitro in the presence of either one of the following dyes as a hydrogen acceptor; 2,6-dichlorophenolindophenol, phenazine methosulfate or potassium ferricyanide. NAD or NADP were not effective as hydrogen acceptor. Substrate specificity of this enzyme with potassium ferricyanide is summarized in Table III. Primary aliphatic alcohols having carbon chain length of 6 or less were rapidly oxidized but not methanol. Secondary and tertiary alcohols and aromatic alcohols could not oxidize to appreciable extent so far tested. Profile of substrate specificity of this enzyme was quite similar to that from cytochrome $c$ of

Table III. Substrate Spectfictty of Particulate Alcohol Dehydrogenase FROM Gluconobacter suboxydans

The reaction rate with ethanol is expressed as 100 .

\begin{tabular}{lc}
\multicolumn{1}{c}{ Substrate } & Relative rate \\
\hline Methanol & 2 \\
Ethanol & 100 \\
$n$-Propanol & 93 \\
$n$-Butanol & 81 \\
$n$-Pentanol & $64^{a}$ \\
$n$-Hexanol & $41^{a}$ \\
Isopropanol & 0 \\
tert-Butanol & 0 \\
Benzylalcohol & $0^{a}$ \\
Phenethylalcohol & $0^{a}$ \\
Formaldehyde & 0 \\
Acetaldehyde & 0 \\
Propionaldehyde & 0 \\
Benzaldehyde & $0^{a}$ \\
Glycerol & 0 \\
Glucose & 0 \\
Glycolate & 0 \\
Lactate & 0 \\
\hline
\end{tabular}

a Enzyme reaction was carried out in the presence of $0.2 \%$ Triton $\mathrm{X}-100$. 
A. peroxydans. ${ }^{24)}$ Substrate specificity of this enzyme as a typical primary alcohol dehydrogenase also likes to those from methanol utilizing bacteria ${ }^{42 \sim 44)}$ except that the enzyme from acetic acid bacteria could not oxidize methanol at all and showed no ammonium ion requirement in the alcohol dehydrogenase activity. The profile of substrate specificity of this enzyme was also similar to those of NADlinked alcohol dehydrogenase from yeast ${ }^{45}$ and horse liver. ${ }^{46}$ An apparent Michaelis constant for ethanol was examined to be $1.6 \times$ $10^{-3} \mathrm{M}$ (Fig. 9), which was almost same order obtained with the enzyme of $A$. peroxydans. ${ }^{24)}$ This value is also similar to that of horse liver enzyme and about one tenth of that obtained with an yeast NAD-dependent alcohol dehydrogenase. $\left.{ }^{45}\right)$

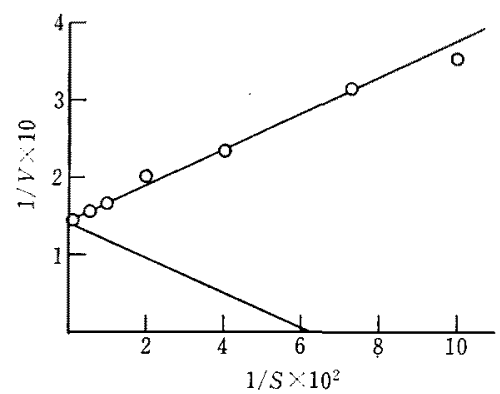

FIG. 9. Effect of Substrate Concentration on Enzyme Activity.

[R Finally purified enzyme with a specific activity of 195 was used. Enzyme activity was measured at various concentrations of ethanol as indicated.

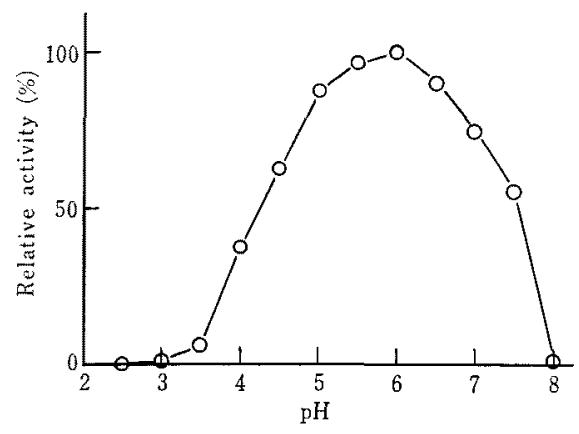

FIG. 10. Effect of pH on Enzyme Activity.

Finally purified enzyme with a specific activity of 195 was used. Enzyme activity was assyad under the standard assay conditions except that the $\mathrm{pH}$ of buffer (Mcllvaine buffer) was varied as indicated.
Optimum $\mathrm{pH}$ of ethanol oxidation was shown in Fig. 10, and the enzyme showed its maximum activity at $\mathrm{pH} 5$ to 6 . Apart from this $\mathrm{pH}$ region, enzyme activity was gradually decreased. It was a marked difference in $\mathrm{pH}$ optima when the enzyme was compared with those of primary alcohol dehydrogenase of methanol utilizing bacteria $a^{42 \sim 44}$ or NADlinked alcohol dehydrogenase from yeast and mammals, ${ }^{45 \sim 46)}$ which unexceptionally show their maximal reaction rate at fairly alkaline $\mathrm{pH}$. It is quite reasonable for acetic acid bacteria to have a $\mathrm{pH}$ optimum of alcohol oxidation at fairly acidic pH. Ethanol content could be well assayed at acidic $\mathrm{pH}$ by the particulate alcohol dehydrogenase of acetic acid bacteria and could be applied to determine the ethanol content of brewing samples without any preadjustment of samples' $\mathrm{pH}$. An attempt for this purpose was reported elsewhere. ${ }^{30}$ )

\section{Effect of Triton $X-100$ to the particulate alcohol dehydrogenase}

Particulate alcohol dehydrogenase has thus purified to homogeneous state from the membrane fraction of acetic acid bacteria. Triton $\mathrm{X}-100$ was used throughout in this study. It is thought that proteins localized in the particulate fraction or anchored to the cellular membrane have some hydrophobicity in its protein molecule and quite hard to make a solution without the aid of detergents. ${ }^{47}$ Nakayama ${ }^{24}$ prepared a cytochrome $\mathrm{c}$ having an alcohol dehydrogenase activity from cell of $A$. peroxydans to almost homogeneous state. He treated the cell as acetone dried cell and, thereafter, the purification of the enzyme was fairly well processed like a soluble enzyme without any aid of detergent. Judging from the data obtained in this study, our enzyme preparation had just a half of molecular size of Nakayama's preparation on the basis of sedimentation constant and molecular weight. Another preparation of particulate alcohol dehydrogenase from $A$. aceti also showed of its molecular weight to be approximately $150,000{ }^{16}$ ) As shown in Fig. 11, dimeric 


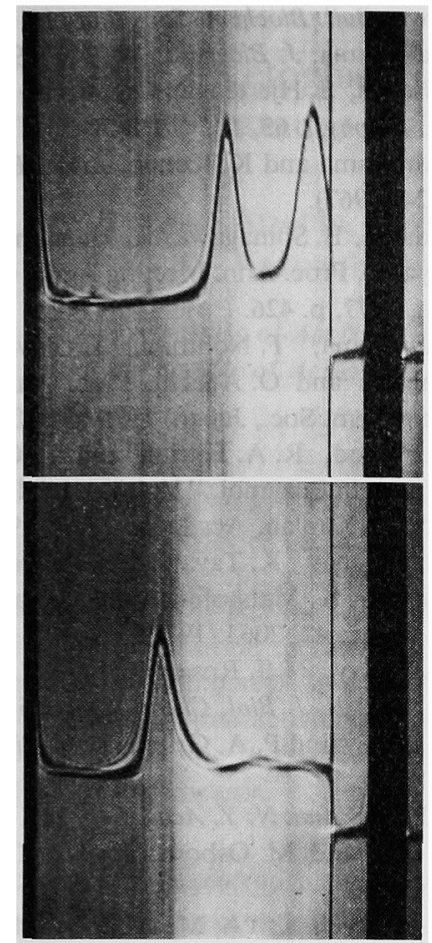

FIG. 11. Effect of Triton X-100 on Particulate Alcohol Dehydrogenase in Analytical Ultracentrifugation.

Finally purified enzyme with a specific activity of 195 was used. Upper frame, monomer of enzyme in the presence of excess amount of Triton X-100. Enzyme protein $(11.0 \mathrm{mg}$ per $\mathrm{ml})$ in $0.01 \mathrm{M}$ buffer containing about $0.1 \%$ Triton $\mathrm{X}-100$. Lower frame, dimer of enzyme in the deficience of Triton X-100. Monomer enzyme was once adsorbed into a small column of hydroxylapatite $(1 \times 1 \mathrm{~cm})$, which had been equilibrated with $0.01 \mathrm{M}$ buffer. After washing the column with the buffer to remove Triton X-100 thoroughly, the enzyme was eluted with $0.2 \mathrm{M}$ buffer and enzyme solution was further concentrated, when necessary. Concentration of dimer was adjusted to $11.0 \mathrm{mg}$ per $\mathrm{ml}$. Both photographs were taken at $44 \mathrm{~min}$ after reaching at $59,780 \mathrm{rpm}$. Direction of sedimentation was right to left.

formation was observed when the enzyme was freed from excess Triton $\mathrm{X}-100$ and run in analytical ultracentrifuge. An apparent sedimentation constant of the dimeric enzyme was found to be $9.8 S$ that was comparable to Nakayama's preparation $(10.3 S)$ and molecular weight was also increased to 320,000 when analyzed by Sepharose $6 \mathrm{~B}$ column. Dimeric enzyme was spontaneously dissociated into monomer by the addition of excess amount of Triton X-100. A trace amount of monomeric enzyme can be seen in the sedimentation profile of dimeric enzyme (Fig. 11, lower frame).

In our preparation, Triton $\mathrm{X}-100$ was found to be useful detergent to solubilize the enzyme from the particulate fraction and the detergent also showed some stabilizing effect when the enzyme was stored as a solution. The enzyme of particulate membrane fraction was quite stable, but once treated and solubilized by a detergent, the enzyme often became labile. It is quite probable that some molecules of Triton X-100 must be associated with the enzyme of hydrophobic region, since the enzyme preparation which was freed from the excess detergent still showed a deep absorption peak around 270 to $290 \mathrm{~nm}$ in the ultraviolet range. Partial decrease in specific activity was observed with the dimeric enzyme and resumed to its original activity by the addition of Triton $\mathrm{X}-100$. Dimeric enzyme could be formed by interaction between hydrophobic regions of two enzyme molecules under the conditions that the detergent is deficient.

Further characterization on the particulate alcohol dehydrogenase in connection with vinegar fermentation and reconstitution study of the enzyme from its subunits are under progress. As described above, glucose dehydrogenase, gluconate dehydrogenase, ketogluconate dehydrogenase, glycerol dehydrogenase, sorbitol dehydrogenase $\mathrm{e}^{11 \sim 14,21,22)}$ have also been purified and characterized to compose an enzyme complex as flavo-cytochrome protein. A group of these enzymes are specifically coupled with electron transfer systems in acetic acid bacteria and other oxidative bacteria. In other words, fermentative production of gluconate, ketogluconate, acetate and so on by these bacteria are strongly associated with their respiratory systems. We believe that further characterization of these enzyme systems should lead us to complete understanding of the nonphosphorylative oxidative metabolism of carbohydrates in acetic acid bacteria and other oxidative bacteria. 
Acknowledgement. We wish to thank Dr. T. Yamanaka, Osaka University, for his valuable advice during the course of this study.

\section{REFERENCES}

1) T. Asai, "Acetic Acid Bacteria," Univ. of Tokyo Press, 1968, p. 5.

2) T. Asai, ibid., p. 103.

3) J.J. Stubbs, L.B. Lockwood, E.T. Roe, B. Tabenkin and G. E. Ward, Ind. Eng. Chem., 32, 1626 (1940).

4) L. B. Lockwood, B. Tabenkin and G. W. Ward, J. Bacteriol., 42, 51 (1941).

5) Y.Ikeda, Bull. Agric. Chem. Soc. Jpn., 24, 151 (1951).

6) J. Deley, Biochim. Biophys. Acta, 27, 652 (1958).

7) T. Chiyonobu, O. Adachi and M. Ameyama, Agric. Biol. Chem., 37, 2871 (1973).

8) M. Ameyama, T. Chiyonobu and O. Adachi, ibid., 38, 1377 (1974).

9) T. Chiyonobu, E. Shinagawa, O. Adachi and M. Ameyama, ibid., 39, 2263 (1975).

10) T. Chiyonobu, E. Shinagawa, O. Adachi and M. Ameyama, ibid., 40, 175 (1976).

11) E. Shinagawa, T. Chiyonobu, O. Adachi and M. Ameyama, ibid., 40, 475 (1976).

12) M. Ameyama, O. Adachi, T. Chiyonobu and E. Shinagawa, Proc. Fifth Intl. Ferment. Symp., Berlin, 1976, p. 165.

13) E. Shinagawa, O. Adachi, K. Matsushita and M. Ameyama, Proc. Ann. Meeting Agric. Chem. Soc., Japan, 1977, p. 427 and 1978, p. 331.

14) K. Matsushita, M. Sakamoto, K. Wada, E. Shinagawa, O. Adachi and M. Ameyama, Proc. Ann. Meeting Agric. Chem. Soc., Japan, 1978, p. 331.

15) O. Adachi, T. Chiyonobu, E. Shinagawa, K. Matsushita and M. Ameyama, Agric. Biol. Chem., 42, 2057 (1978).

16) O. Adachi, K. Tayama, E. Miyagawa, E. Shinagawa, K. Matsushita and M. Ameyama, Proc. Ann. Meeting Agric. Chem. Soc., Japan, 1978 p. 119.

17) M. Ameyama, T. Chiyonobu and O. Adachi, Agric. Biol. Chem., 38, 1535 (1974).

18) T. Chiyonobu, O. Adachi and M. Ameyama, ibid, 38, 1743 (1974).

19) T. Chiyonobu, E. Shinagawa, O. Adachi and M. Ameyama, ibid., 39, 2425 (1975).

20) M. Ameyama, Int. J. Syst. Bacteriol., 25, 365 (1975)

21) K. Matsushita, O. Adachi, E. Shinagawa and M. Ameyama, J. Biochem., 83, 171 (1978).

22) E. Shinagawa, T. Chiyonobu, K. Matsushita, O. Adachi and M. Ameyama, Agric. Biol. Chem., 42, 1055 (1978).

23) I. Sekuzu, K. Okunuki, T. Nakayama and T.
Hosoya, Bull. Biochem. Soc., Jpn., 39, 691 (1967).

24) T. Nakayama, J. Biochem., 49, 240 (1961).

25) A. Tiselius, S. Hjerten and O. Levin; Arch. Biochem. Biophys., 65, 132 (1956).

26) M. Ameyama and K. Kondo, Agric. Biol. Chem., 31, 724 (1967).

27) O. Adachi, E. Shinagawa, K. Matsushita and M. Ameyama, Proc. Ann. Meeting Agric. Chem. Soc. Japan, 1977, p. 426.

28) M. Ameyama, T. Nohtomi, T. Chiyonobu, E. Shinagawa and O. Adachi, Proc. Ann. Meeting Agric. Chem. Soc., Japan, 1975, p. 130.

29) W. A. Wood, R. A. Fetting and B. C. Hertlein, "Methods in Enzymol.," Vol. V, ed. S.P. Colowick and N. O. Kaplan, Academic Press, 1962, p. 287.

30) M. Ameyama, K. Tayama, E. Miyagawa, E. Shinagawa, K. Matsushita and O. Adachi, Agric. Biol. Chem., 42, 2063 (1978).

31) O. H. Lowry, N. J. Rosebrough, A. L. Farr and R. J. Randall, J. Biol. Chem., 193, 265 (1951).

32) J. R. Dulley and P. A. Grieve, Anal. Biochem., 64, 136 (1975).

33) B. J. Davis, Ann. N. Y. Acad. Sci., 121, 404 (1964).

34) K. Weber and M. Osborn, J. Biol. Chem., 244, 4406 (1969).

35) C. H. Chervenka, "A Mannual of Methods for the Analytical UItracentrifuge," Beckman Instruments Inc., Palo Alto, California, 1970 p. 23.

36) E. Shinagawa, T. Chiyonobu, O. Adachi and M. Ameyama, Proc. Ann. Meeting Agric. Chem. Soc. Japan, 1976, p. 95.

37) K. Okunuki and T. Yamanaka, "Cytochromes," (in Japanese), Asakura-shoten, Tokyo, 1970, p. 3.

38) "Studies on Cytochromes," (in Japanese), a collection of themes in commemoration of retirement of Prof. Okunuki, ed. by Prof. Okunuki's colleagues, Univ. Tokyo Press, Tokyo, 1973, p. 3.

39) T. Yamanaka and K. Okunuki, "Cytochromes of Microorganisms," (in Japanese), Kohdanshascientific, Tokyo, 1975, p. 10 and p. 104.

40) H. R. Maurer, "Disc Electrophoresis and Related Techniques of Poly Acrylamide Gel Electrophoresis," Walter de Gruyter, Berlin, 1971, p. 148.

41) H. R. Maurer, ibid., p. 76.

42) R. N. Patel, H. R. Bose, W. J. Mandy and D.S. Hoave, J. Bacteriol., 110, 570 (1972).

43) G. T. Sperl, H. S. Forrest and D. T. Gibbon, ibid, 118, 541 (1974).

44) K. Yamanaka and K. Matsumoto, Agric. Biol. Chem., 41, 476 (1977).

45) H. Sund and H. Theorell, "The Enzymes," Vol. 7, 2nd ed. by P. D. Boyer, H. Lardy and K. Myrbäck, Academic Press, 1963, p. 57.

46) H. Sund and H. Theorell, ibid., p. 31.

47) A. Helenius and K. Simons, Biochim. Biophys. Acta, 415, 29 (1975). 